\title{
Avalanche Defence Strategies and Monitoring of Two Sites in Mountain Permafrost Terrain, Pontresina, Eastern Swiss Alps
}

\author{
MARCIA PHILLIPS ${ }^{\star}$ \\ WSL, Swiss Federal Institute for Snow and Avalanche Research SLF, Flüelastrasse 11, \\ CH-7260, Davos Dorf, Switzerland
}

(Received: 28 May 2004; accepted: 5 December 2005)

\begin{abstract}
Snow-supporting avalanche defence structures are increasingly being built at high altitudes in potential permafrost areas. Special construction methods and guidelines have been developed to ensure a minimal stability of the structures, which have a vital role in the protection of underlying settlements and transport infrastructure against snow avalanches. If the avalanche slopes are located on ice-rich permafrost terrain, as is the case in a steep avalanche gully above Pontresina (Eastern Swiss Alps), other means of protection must be used - such as deflection or retention dams - as construction on ice-rich sediments can be very problematic. Experimental snow-supporting structures were built in 1997 in order to test different types of structures and their foundations, to develop specially adapted construction methods and to monitor the long-term behaviour of the structures in moderately creeping frozen ground with volumetric ice contents under $20 \%$. Snow-nets were found to be the most suitable type of protection against avalanches in this type of permafrost terrain due to their deformability and because they are well adapted to rock fall. The structures do not improve slope stability but contribute towards maintaining permafrost as they delay snow melt by modifying the spatial and temporal distribution of the snow cover. The results of the project described have led to a better understanding of permafrost-related avalanche defence problems.
\end{abstract}

Keywords: snow-supporting structures, avalanches, ice-rich permafrost, slope stability, ground temperature

\section{Introduction}

In the Alps permafrost or permanently frozen ground is mainly found at high altitudes, above about 2,500 $\mathrm{m}$ ASL and consequently, relatively little infrastructure is directly affected - mainly mountain huts, cable car stations and avalanche defence structures are constructed there (Haeberli, 1992). In the latter category, snow-supporting structures, which are designed to retain snow on steep slopes in avalanche starting areas, are frequently located at high altitudes, as they have to be built at the top of slopes in avalanche

\footnotetext{
$\star$ Author for correspondence: Phone: +41-81-417-02-18; Fax: +41-81-417-01-10; E-mail: phillips@slf.ch
} 
starting areas. Tourism in the Alps has led to a steady increase in the size of settlements and in the density of vehicles on transport routes, implying that safety requirements are changing and the requirement for protection against avalanches has risen. Snow-supporting structures are therefore also increasingly being built in permafrost terrain. There are currently 15-20 zones equipped with snow-supporting structures located in permafrost in the Swiss Alps (Stoffel, 1995). In the literature there are no references to snow-supporting structures in permafrost in other Alpine countries such as Austria, Italy or France, although they have many structures and similar avalanche and permafrost conditions. In less densely populated mountainous areas (e.g. in USA, Russia or Canada) snow-supporting structures are hardly used at all (personal communication, S. Margreth).

First attempts at building snow-supporting structures in permafrost rapidly showed that freezing ground temperatures, ice-rich terrain and unstable slopes caused technical problems and that special measures would have to be taken to ensure adequate protection against avalanches if these types of structures were to be used effectively (Haefeli, 1954; Stoffel, 1995).

The first documented reference to potential problems concerning the building of snow-supporting structures in permafrost was made by Haefeli (1954), who emphasized that the effect of the structures on ground temperature and stability was not known, but that artificial modifications in snow cover distribution induced by the presence of the structures could lead to changes in frost penetration and hence to modifications of ground ice content - and therefore possibly to a reduction of slope stability. This observation was made at an early stage in the history of the structures, as the avalanche disaster of 1951 (causing 98 deaths in Switzerland) was the main catalysing factor leading to the construction of over $500 \mathrm{~km}$ of structures existing in the Swiss Alps today (Margreth et al., 2000).

At present, engineers and foresters responsible for the construction of snow-supporting structures encounter construction problems related to the presence of ice in the ground and due to freezing ground temperatures. Various technical questions have arisen, for example, on the strength of anchors in permafrost and on the compressive strength of grout in negative thermal conditions, as the grout tends to freeze before hardening, leading to reduced compressive strength. In order to reach the bedrock, the anchors, which are typically $3-10 \mathrm{~m}$ long, have to penetrate the active layer, the topmost part of the ground which melts in summer. This often consists of a mixture of loose rocks, ice, water and air, and is subject to creep. Observations of damages to structures located in creeping permafrost terrain have been made, for example at Wisse Schijen, Randa (Canton Valais, south-western Switzerland), where a row of snow bridges was displaced $1.5 \mathrm{~m}$ downslope between 1990 and 1995 and subsequently had to be rebuilt elsewhere, incurring substantial costs (Phillips et al., 2003a). 
Drilling boreholes to anchor the snow-supporting structures can be particularly difficult in ice-rich terrain because slope angles are steeper (leading to collapse of the boreholes) and because the presence of ice in sedimentary deposits can cause mud-clogging during drilling, due to friction melting (Phillips, 2000). Grouting of anchors is problematic at subfreezing temperatures because the grout typically freezes during the curing process, before attaining the required compressive strength of $35 \mathrm{MPa}$ after 28 days (SLF/BUWAL, 1990). At many sites, rock fall damages the steel structures, particularly in warm summers when active layer thickness increases in the surrounding rock outcrops and scree (Figure 1).

As snow-supporting structures are expensive (1,000-1,600 Euros per metre-length), mainly due to high transportation costs, it is essential that

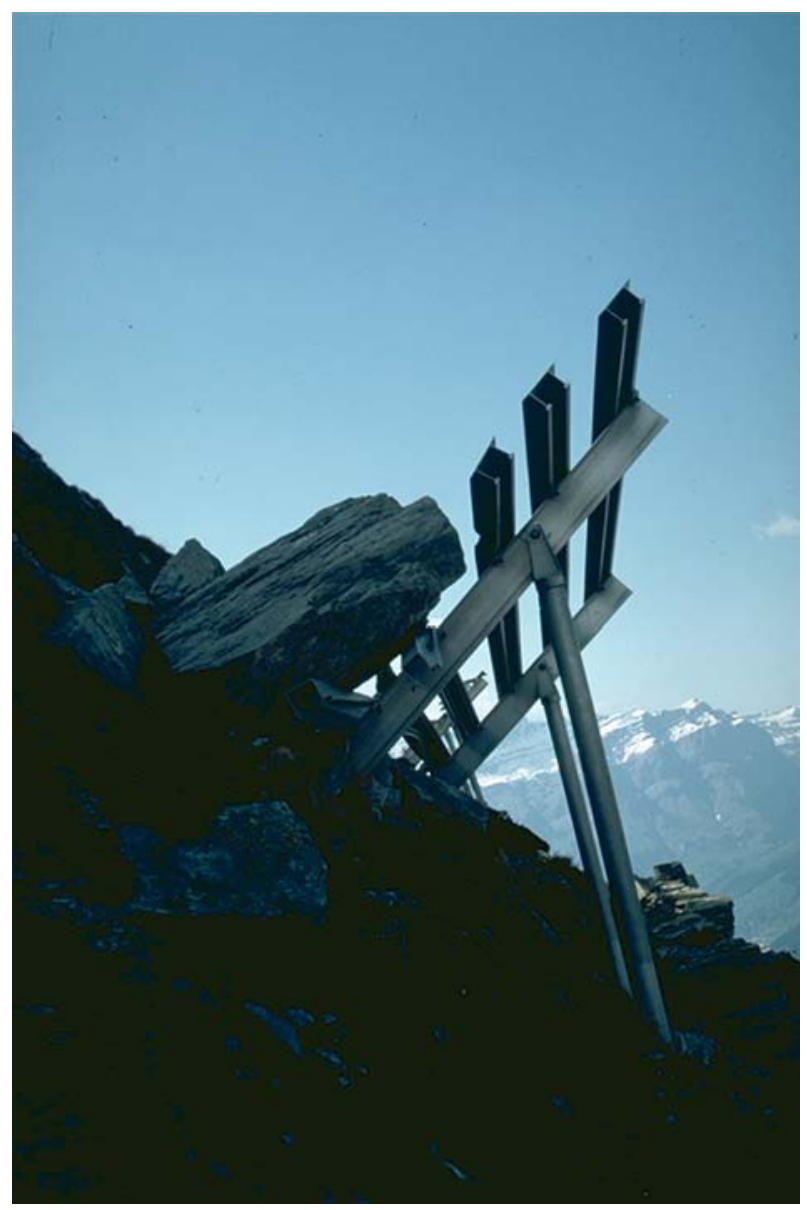

Figure 1. Snow bridge in permafrost terrain damaged by rock fall (Emshorn, Valais, 1996). 
they are built in an efficient manner, ensuring a long durability. The project entitled "Snow-supporting structures in permafrost" was started at the Swiss Federal Institute for Snow and Avalanche Research (SLF) in 1996, with the aims of determining whether and how the structures could be built in alpine permafrost regions - and whether they have any long-term influence on the thermal regime and stability of the frozen ground (Phillips, 2000; Thalparpan 2000; Phillips et al., 2003b).

This paper focuses on the problem of installing appropriate avalanche defence structures in permafrost terrain. Snow-supporting structures were tested and monitored in moderately creeping permafrost terrain, with low volumetric ice content. In addition, the monitoring of the thermal regime and stability of an ice-rich avalanche starting zone where the construction of avalanche defence structures is not possible is described. The project combines geotechnical, engineering and thermal investigations on avalanche slopes and has led to a better understanding of permafrost-related problems in the field of avalanche defence construction.

\section{Study Sites}

Pontresina is a village with a population of 1,850 (and an additional 6,700 tourists during the winter season) in the eastern Swiss Alps and has a long history of avalanche defence strategies - as early as 1910 the area equipped with snow-supporting structures above Pontresina was the largest in Switzerland (Coaz, 1910). There are currently over $15 \mathrm{~km}$ of structures on the slopes above the village, including dry stone walls (first built around 1880), concrete structures and modern steel snow-bridges. They are located in the avalanche starting areas northeast of the village and retain snow on these slopes, preventing the formation of avalanches.

One sector of the slope above Pontresina, the Laviner Giandains gully, has not been equipped with snow-supporting structures of any kind. The top of the avalanche gully is occupied by a steep, ice-rich rock glacier tongue. Large avalanches triggered in this sector and affecting the village notably occurred in 1964, 1969, 1975, 1985, 1994 and 2001 (Stoffel, 1995), emphasizing the need for protective structures (Figures 2 and 3).

The steep slopes above Pontresina provide an ideal context for a combination of natural hazard monitoring and applied research. The essential elements for the construction of avalanche defence structures and for the investigation of the stability of unconsolidated sediments in permafrost are all present: steep slopes, ice-rich permafrost sediments, and the existing requirement for efficient defence against avalanches and debris flows. Measurements are effected at two sites, Laviner Giandains (site 1) and Muot da Barba Peider (site 2) (Figure 4 and 5). 


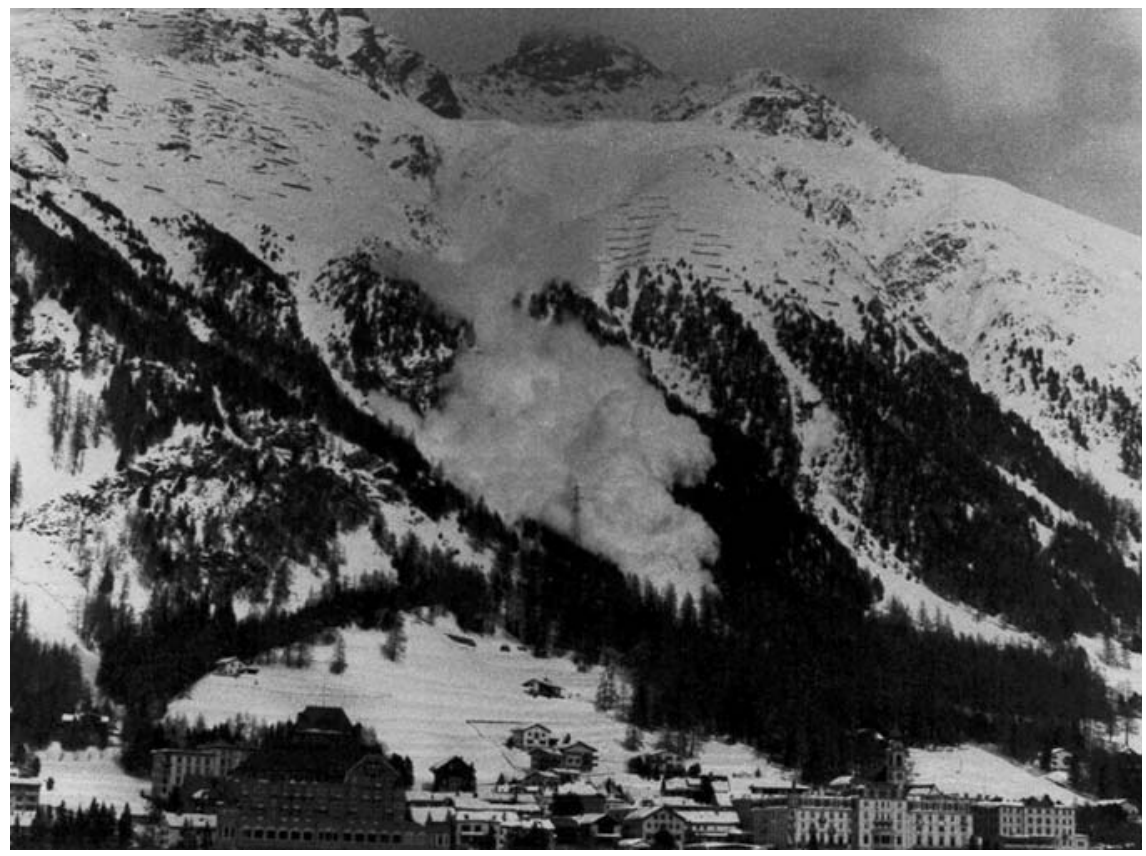

Figure 2. Avalanche triggered in the Laviner Giandains starting zone above Pontresina in 1975 (Photograph: Avalanche service, Pontresina).

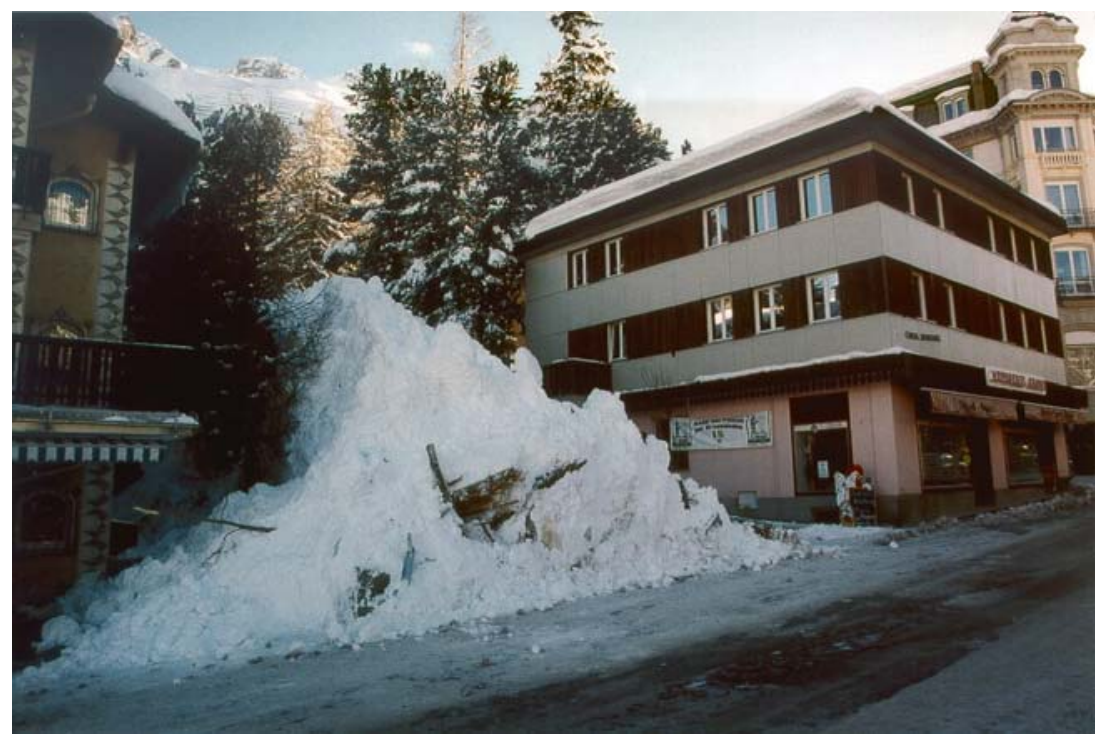

Figure 3. Avalanche deposit on the road in the village in 2001 (Photograph: F. Techel). 


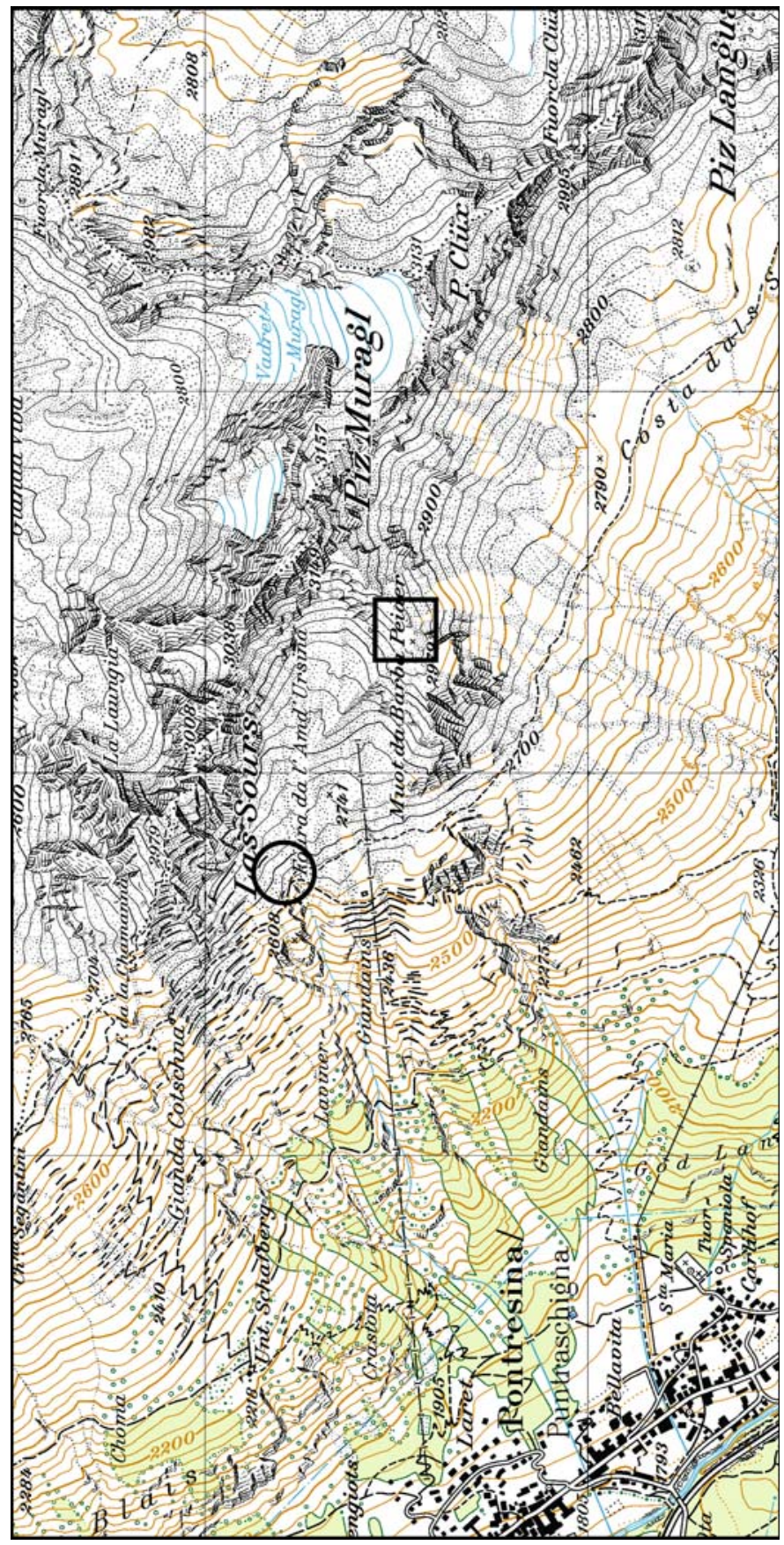

N

$\stackrel{\oplus}{=}$

चृ

$\frac{0}{0}: \Xi$

范

ช

긍

$\stackrel{2}{\Xi}$

용

$\cong \Phi$

ᄀ

谟 气

ஓं 용

กิ

$\stackrel{\frac{\pi}{0}}{2}$

苍啇

过

ब

苛 苛.

ค.

$\stackrel{2}{2}$

요

으

종

-

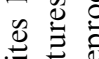

क

冚宾方

क D

을

$\leftarrow$ 응

궁

歾

으 至

따 है

미 0

焉至

응.

क

这

$\therefore$ 节

$\therefore$ -

选究䒕 


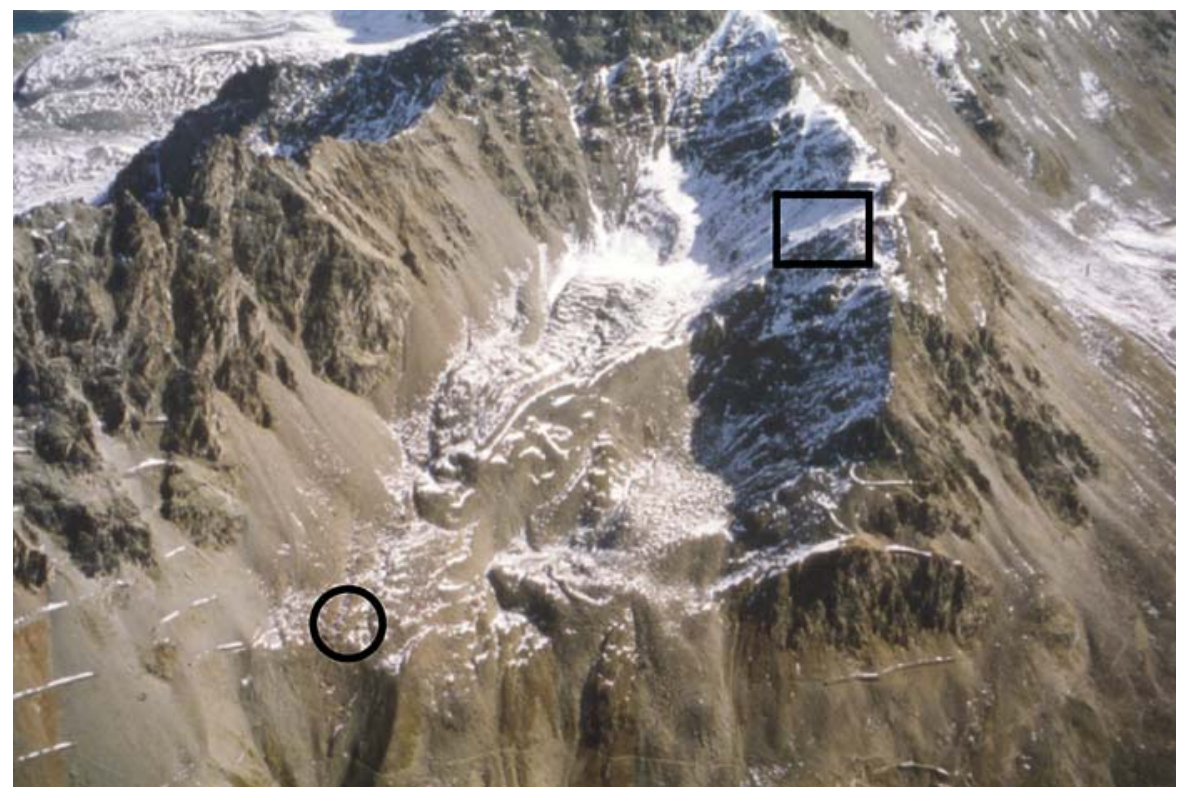

Figure 5. Aerial photograph showing the location of study sites 1 and 2. (Photograph: M. Hoelzle). Site 1 is shown by a circle and Site 2 by a square.

\subsection{SITE 1: LAVINER GIANDAINS ROCK GLACIER TONGUE}

The top of the Laviner Giandains avalanche gully is a $36^{\circ}$ steep west oriented blocky slope above Pontresina (Figures 4 and 5). It forms the tongue of the rock glacier complex Foura da l'Amd' Ursina located west of Piz Muragl. The steep part of the slope reaches from 2550 to $2720 \mathrm{~m}$ ASL.

Attempts to effect anchor pull-out tests in 1987 indicated that construction in the Laviner Giandains avalanche starting zone would be impossible, as drilling was extremely difficult in this ice-rich terrain (Heimgartner, 1988; Stoffel 1995). In addition, the slope was considered to be a potential release area for large debris flows in summer (Keller et al., 2002). These findings had two consequences: firstly, a project was started to determine whether and how avalanche defence structures can be built in permafrost terrain (Phillips, 2000; SLF/BUWAL, 2000; Thalparpan, 2000). Secondly, the Laviner Giandains slope had to be monitored using borehole deformation and temperature measurements and an alternative type of avalanche protection was designed. This resulted in the construction of a combined avalanche/debris flow retention dam just above the village in 2003 (Figure 6). Assuming a potential debris flow starting area of $0.8 \mathrm{~km}^{2}$, it was estimated that $25,000-100,000 \mathrm{~m}^{3}$ of debris could be mobilized and the dam was designed accordingly - to retain $100,000 \mathrm{~m}^{3}$ of debris flow 


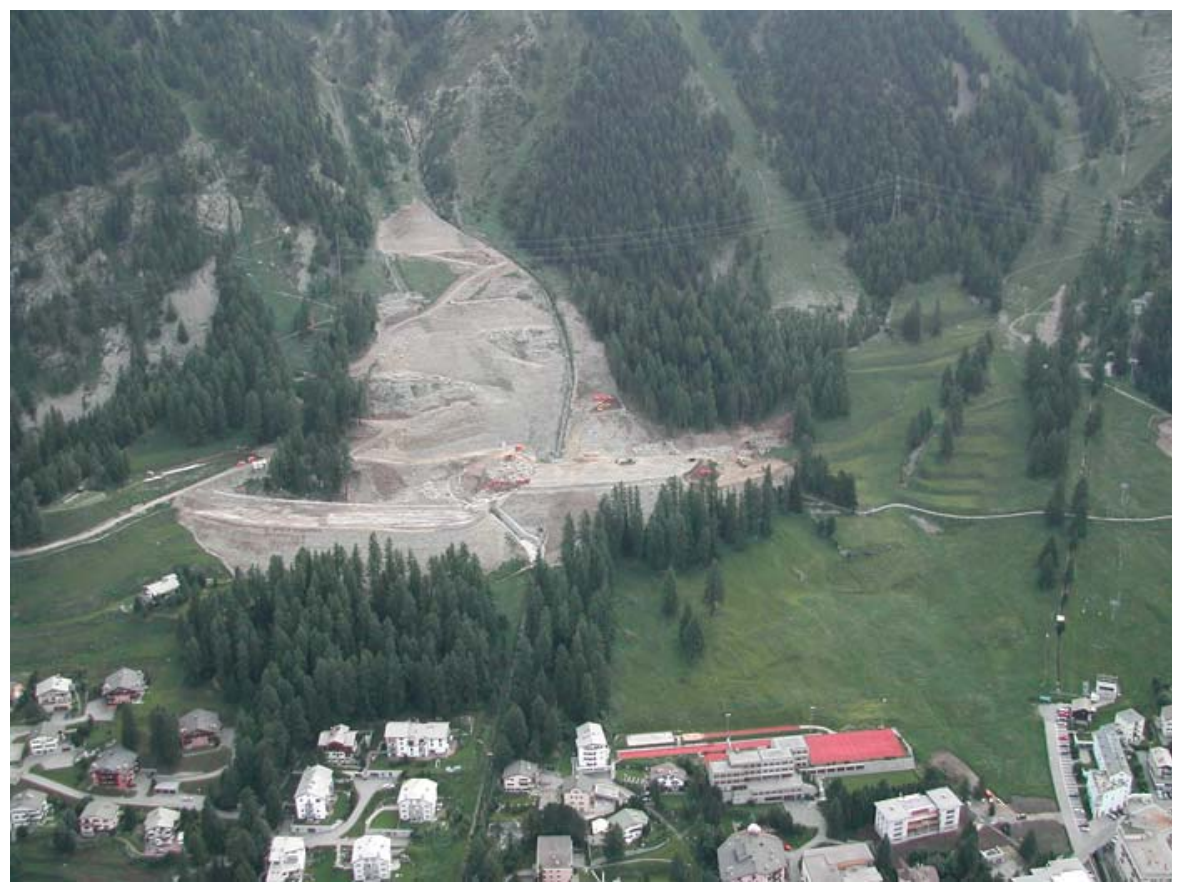

Figure 6. Combined avalanche/debris flow retention dam (under construction in 2003) protecting Pontresina at the foot of the Laviner Giandains gully. (Photograph: M. Hiller SLF).

material or alternatively, $240,000 \mathrm{~m}^{3}$ of avalanche snow in winter (Keller et al., 2002). The avalanche/debris flow triggering zone is of particular interest for Pontresina and has therefore been monitored closely for over a decade in view of the safety of the village (Phillips et al., 2002).

\subsection{SITE 2: MUOT DA BARBA PEIDER EXPERIMENTAL SLOPE}

An avalanche slope which does not affect the village, on Muot da Barba Peider (site 2) (Figures 4 and 5) was chosen in order to develop and test appropriate snow-supporting structures for permafrost, to investigate the thermal regime of permafrost ground on an artificially modified slope, and to monitor their long term behaviour.

In parallel, instruments to monitor slope stability, the ground thermal regime and other influencing factors were installed (Phillips, 2000). New Swiss guidelines for the construction of snow-supporting structures in permafrost terrain were developed based on the data acquired in field and laboratory experiments (SLF/BUWAL, 2000).

The north-western flank of the Muot da Barba Peider ridge is a steep scree slope in permafrost which tends to avalanche naturally in winter. The avalanches do not affect Pontresina as their runout area is on the upper reaches 
of the Foura da l'Amd' Ursina rock glacier. The slope sector being investigated is between 2930 at $2980 \mathrm{~m} \mathrm{ASL}$ with an average slope angle of $38^{\circ}$. The ice content of the ground was determined from borehole cores and is much lower than at Site 1, with volumetric ice contents of 10-15\% (Phillips, 2000).

\section{Methods}

\subsection{BOREHOLE DEFORMATION AND TEMPERATURES}

In 1990 a $37.5 \mathrm{~m}$ borehole was drilled in the rock glacier tongue at Site 1 to monitor the thermal state of the ground and to measure slope stability in the creeping frozen material, which has a maximum volumetric ice content of $80 \%$, which was estimated from borehole logs in the top $15 \mathrm{~m}$ (Vonder Mühll, 1993; Hoelzle et al., 1998). Deformation measurements were effected between 1990 and 1999 (Hoelzle et al., 1998; Arenson et al., 2002), until they had to be ceased because the borehole sheared off at around $26 \mathrm{~m}$ depth in 2000 . The borehole was initially drilled down into the bedrock, which was located at $30 \mathrm{~m}$ (Hoelzle et al., 1998) and equipped with an inclinometer tube. The latter was anchored in the stable bedrock, allowing horizontal deformation in the creeping rock glacier to be measured (VAW, 1992; Phillips et al., 2002). Deformation measurements were effected using a Sinco Digitilt inclinometer (precision $\pm 0.15 \mathrm{~mm} \mathrm{~m}^{-1}$ ).

Continuous automatic borehole temperature measurements have been effected since 1997. Before, they were carried out both manually and automatically (Vonder Mühll and Holub, 1992; Vonder Mühll et al., 1998). The lowest two thermistors were cut off in 2000 but the remaining ones continue to function despite being trapped in the tube. Their presence has rendered further deformation measurements impossible.

The tube contains a chain of 12 YSI 46006 thermistors with a calibrated precision of $\pm 0.1{ }^{\circ} \mathrm{C}$ connected to a Campbell CR10X data logger. Measurements are effected hourly and the daily mean is registered. Currently, the thermistors are located at the following depths: $0,1.2,3.2,5.2,7.2,9.2,13.2$, $17.2,21.2,25.2,29.2,33.2 \mathrm{~m}$, based on the positions of the initial thermistors between 1990 and 1997 (Vonder Mühll and Holub, 1992). The thermistors at 29.2 and $33.2 \mathrm{~m}$ were disconnected in 2000 when the borehole sheared off. The data logger is on the ground surface, protected by a concrete shaft.

In 1996 two $18 \mathrm{~m}$ boreholes (B1 and B2) were drilled at Site 2, in the steep scree slope (Figure 7). The boreholes were tubed and equipped with YSI 46006 thermistors at depths of $0.5,1,2,3,4,6,8,10,13.5$ and $17.5 \mathrm{~m}$. The measurement setup is the same as that at Site 1, using Campbell CR10X loggers and concrete shafts to protect them against rock fall. Temperatures are measured hourly and the daily mean is registered. 


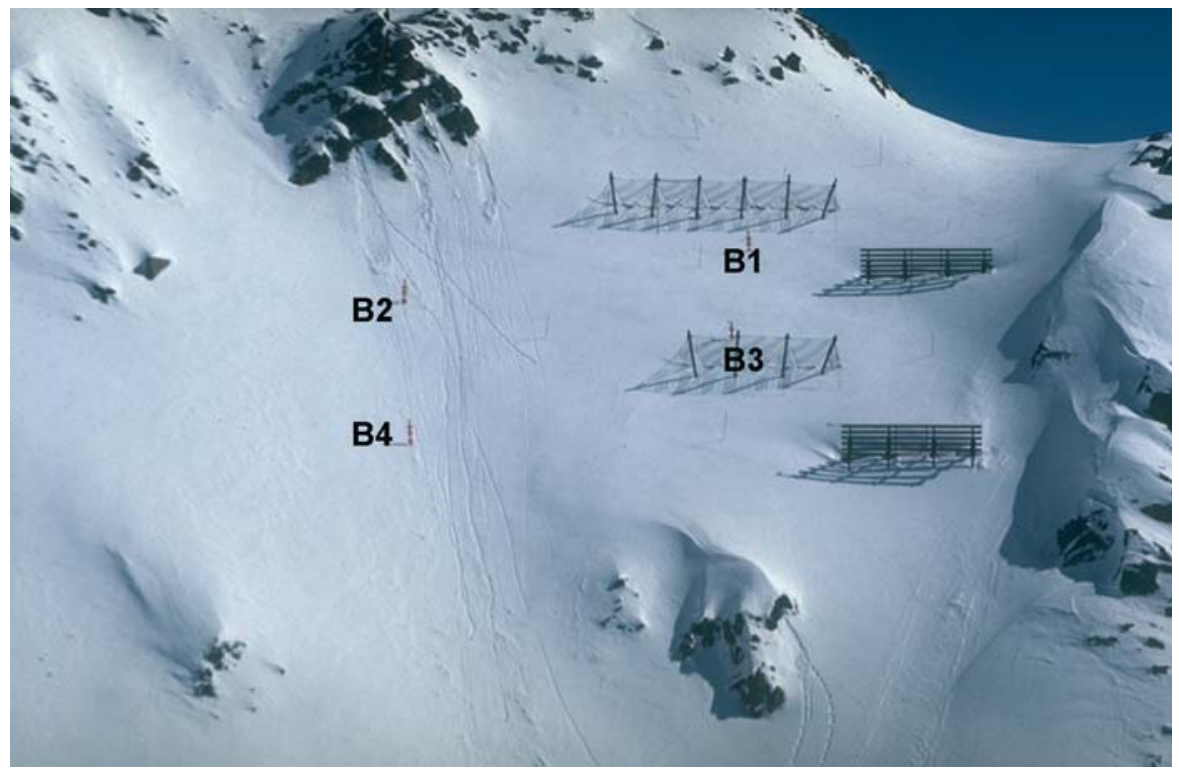

Figure 7. Locations of the boreholes at Site 2 and of the snow-supporting structures which were built in 1997. One temperature- and one inclinometer borehole (B1 and $\mathrm{B} 3$ respectively) are located between the structures, whereas the other two (B2 and B4) are in a reference position on the same slope but further away from the structures. The snow-nets are located on the left, the snow-bridge top right and the suspended sledge bottom right.

Two further boreholes (B3 and B4) were drilled at Site 2 in 1996 to a depth of $6 \mathrm{~m}$ (Figure 7) and were equipped with inclinometer tubes. Deformation measurements are carried out once a year. The stratigraphy and ice content of the ground were determined using cores from these boreholes. The top $1.6 \mathrm{~m}$ consist of blocky scree, which is underlain by $2 \mathrm{~m}$ of silt and stones containing ice $(10-15 \%$ volumetric ice content). The bedrock occurs at $3.6 \mathrm{~m}$ depth in B3 and at $3.8 \mathrm{~m}$ depth in B4 (Phillips, 2000).

\subsection{EXPERIMENTAL SNOW-SUPPORTING STRUCTURES}

Three types of structure were built at Site 2 in 1997: conventional rigid snow-bridges, flexible snow-nets and a specially designed "suspended sledge" construction, a snow-bridge which is only anchored upslope and which can move freely downslope (Figure 8). Statically determined structures, where the different foundations have no stiff connection, are assumed to be suitable in permafrost soils. Four types of foundations were tested in various combinations: micropiles (Gewi bars), cable anchors, steel tubes and plate foundations. Anchor lengths varied between 3 and $6 \mathrm{~m}$, depending on the thickness of the scree above the bedrock, the 

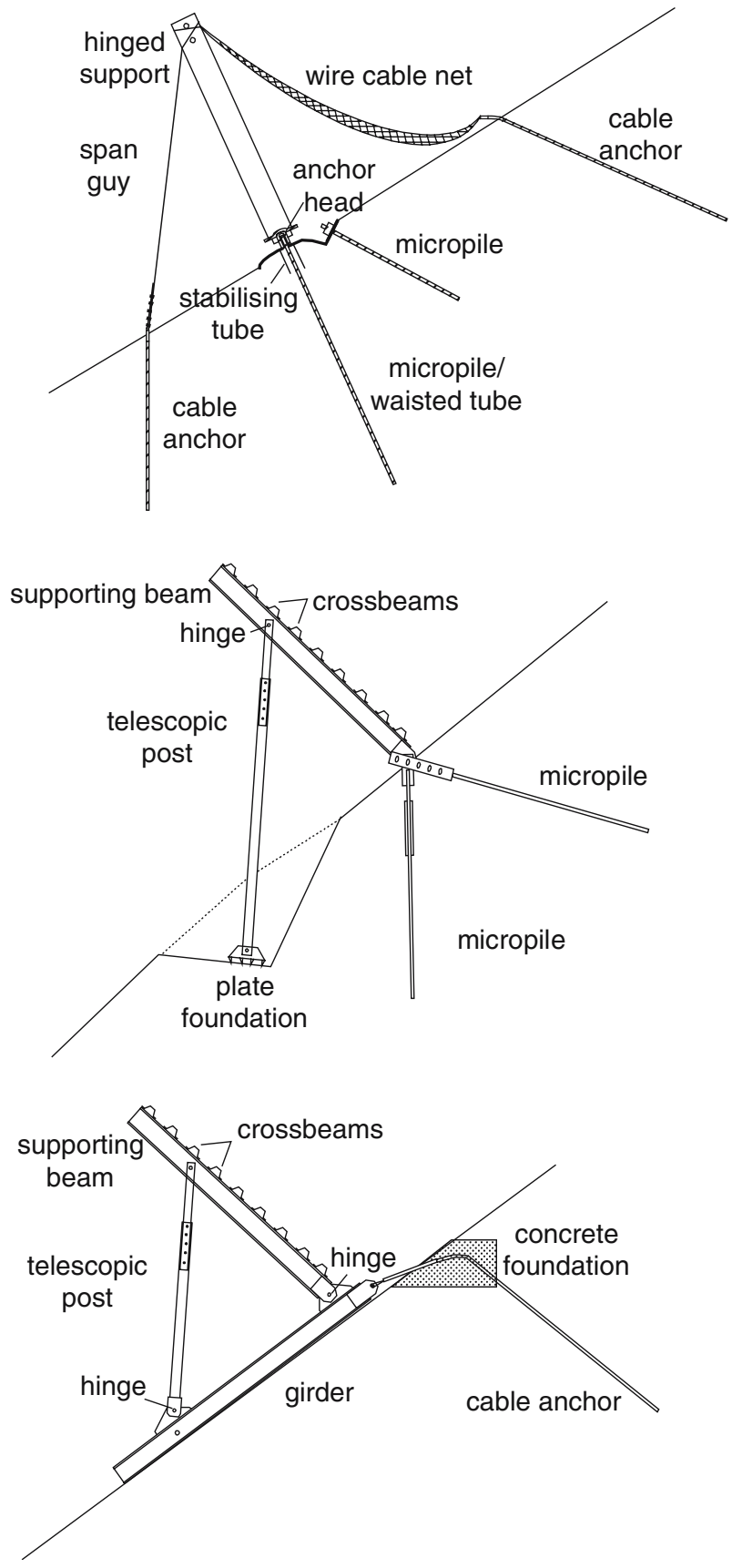

Figure 8. Snow nets (top), snow bridges (centre) and the "suspended sledge" (bottom) developed at SLF. 

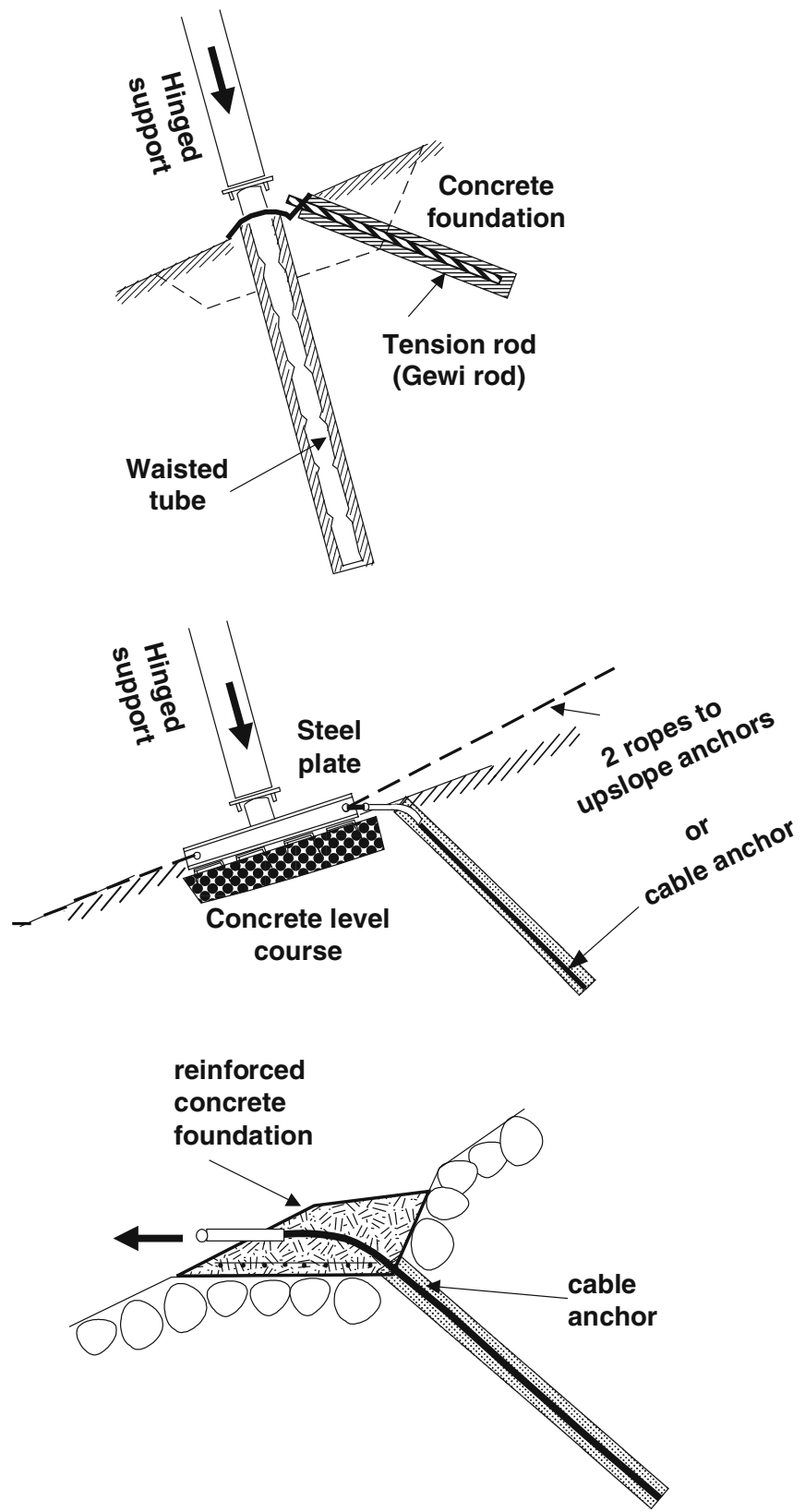

Figure 9. Examples of anchors and foundations used under snow-nets.

compactness of the sediments and the ice content of the ground. Various combinations of anchors and foundations used under snow-nets are shown in (Figure 9). The positions of the anchor heads and of the plate foundations are surveyed yearly, using a Wild TC 1610 theodolite (precision 

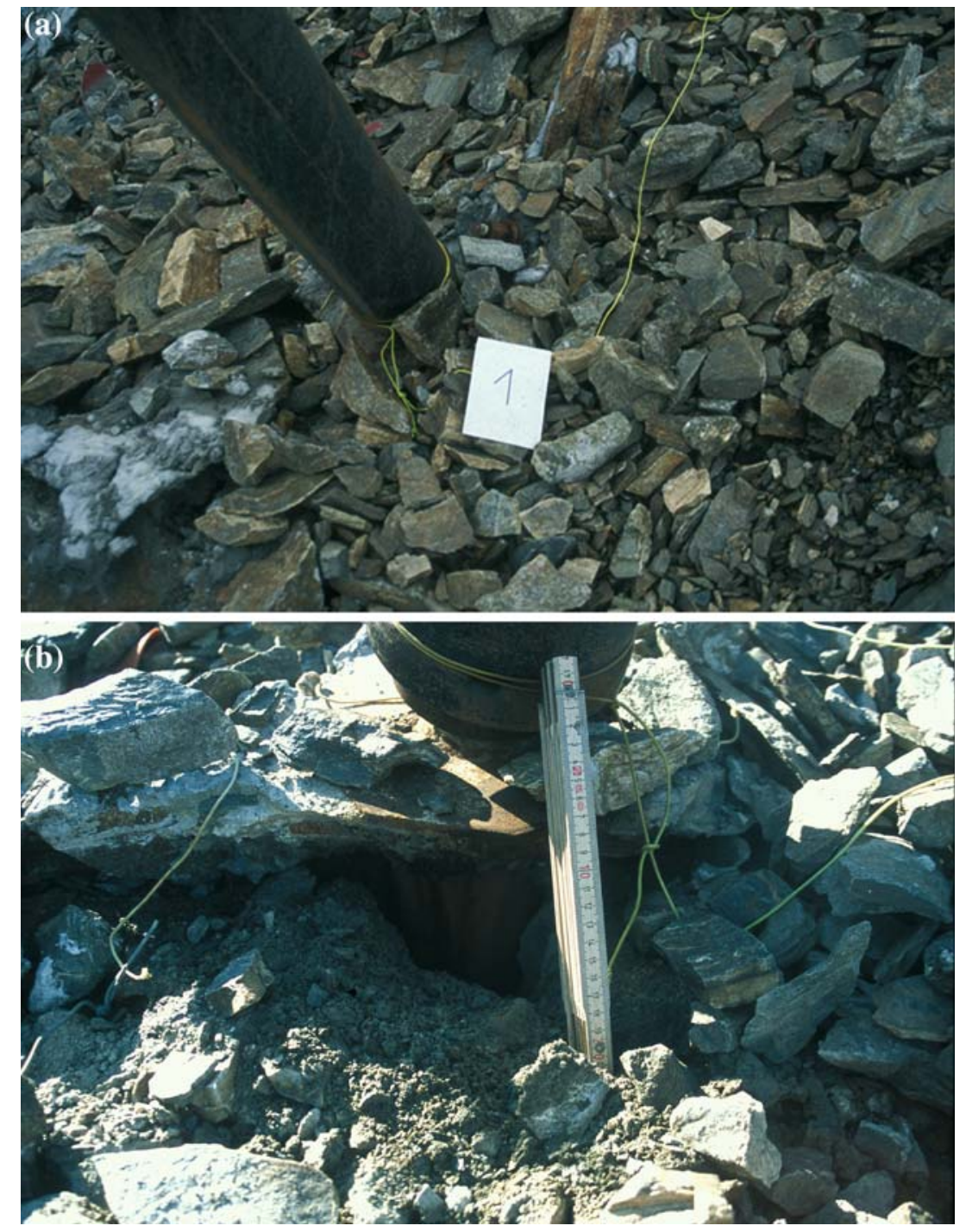

Figure 10. (a) A snow-bridge anchor (micropile) at Site 2 in 1997. (b) The same anchor in 2003 showing the denudation of the top of the anchor and surface erosion of the scree around the anchor head.

$\pm 2 \mathrm{~mm}$ ) and reflectors which are mounted on the foundations or anchor heads. In addition, each element is photographed yearly and changes are recorded (Figures 10a and b).

A selection of anchors, boreholes parallel to the anchors and structure supports (which are above the ground surface) were equipped with YSI 46006 thermistors to determine whether the steel supports conduct heat from the sun into the underlying permafrost via the anchors. 
In addition, specially adapted building methods were tested during the construction of the experimental snow-supporting structures. The anchoring process involves the drilling of a borehole, into which the anchor is placed and which is then filled with injection grout. A minimum grout compressive strength of $35 \mathrm{MPa}$ after 28 days is necessary for attaining sufficient bearing capacity of the anchors (SLF/BUWAL, 1990/2000). Negative ground temperatures (regardless of ice content) induce the injection grout to freeze in the borehole, preventing the completion of the hardening process, which leads to reduced compressive strength of the grout. Grout tests were effected in the laboratory and in the field to investigate grout strength under permafrost conditions, to determine an ideal curing process at negative temperatures and an ideal grout injection temperature (EMPA/ SLF, 1999; Phillips et al., 2003a). Anchor pull-out tests were carried out to determine the bearing capacity of anchors according to ground type and to effect creep tests in permafrost sediments (Phillips et al., 2003a).

\section{Results and Discussion}

\subsection{SITE 1: BOREHOLE MONITORING}

The data obtained at Site 1 since 1997 (Figure 11) indicate that the permafrost is "temperate" (i.e. close to $0{ }^{\circ} \mathrm{C}$ (Delaloye, 2004)), and that the ground is permanently frozen at $5.2 \mathrm{~m}$ depth. Permafrost thickness is around $40 \mathrm{~m}$ and the stratigraphy, which was determined by borehole logging, consists of interspersed layers of blocks and ice underlain by bedrock at $30 \mathrm{~m}$ depth (Vonder Mühll and Holub, 1992). Deformation measurements effected between 1994 and 1997 indicate that the rock glacier is creeping at a slow but steady rate of a few centimetres per year into the Laviner Giandains avalanche gully (Figure 12, Arenson et al., 2002). This confirms the measurements reported by Hoelzle et al. (1998), effected between 1990 and 1994. The mean annual vertical temperature curves (calculated for the hydrological year) show that ground temperatures vary strongly in the upper $10 \mathrm{~m}$ of the ground on an annual basis (Figure 13). The depth of the zero annual amplitude remains fairly stable at around $10 \mathrm{~m}$ depth.

Borehole drilling and anchor pull-out tests effected on the rock glacier tongue at Site 1 indicated that it is ice-rich (Heimgartner, 1988; VAW, 1992). The blocky, highly porous active layer insulates the underlying permafrost to a certain extent and significant thermokarst subsidence of the rock glacier surface such as that observed by Johnson and Nickling (1979) due to melt of interstitial ice has not been measured (Kääb, 1996; Kääb and Völlmer, 2001). Precipitation or snow melt water either runs off downslope at the surface, on the permafrost table (Gardaz, 1998) or refreezes in 


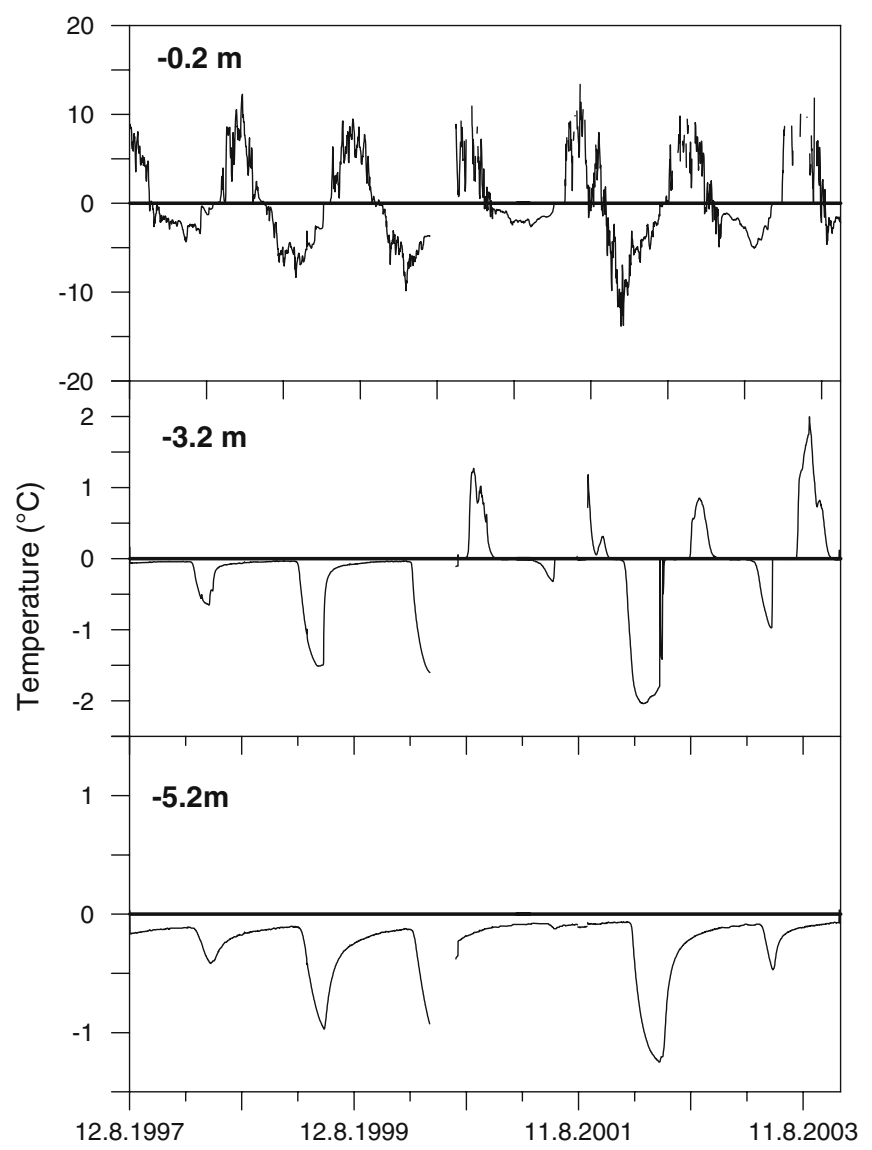

Figure 11. Borehole temperatures measured at $0.2,3.2$, and $5.2 \mathrm{~m}$ depth between 1997 and 2003 at Site 1. Note that the temperature scales are different for each depth. Bold lines denote $0{ }^{\circ} \mathrm{C}$. Gaps in the data are due to battery problems.

the ground. The introduction of relatively warm water into the ground and the release of latent heat through freezing (Hinkel and Outcalt, 1994) has the effect of causing a rapid temperature increase to $0{ }^{\circ} \mathrm{C}$, particularly during spring snow melt (Figure 11). Snow melt water and precipitation affects both the thermal regime of the ground and slope stability (Rist and Phillips, 2005). Debris flows triggering on the steep rock glacier tongue would probably entrain material from the active layer only and not from the underlying ice-cemented rock glacier material (Arenson, 2002). The active layer thickness at the tongue varies significantly from year to year (see also Figure 18) and is probably highly dependent on the duration of the winter snow cover (not measured at this site) and on summer thermal conditions. Due to the unstable and ice-rich nature of the steep slope, it was not technically advisable to build snow-supporting structures there 


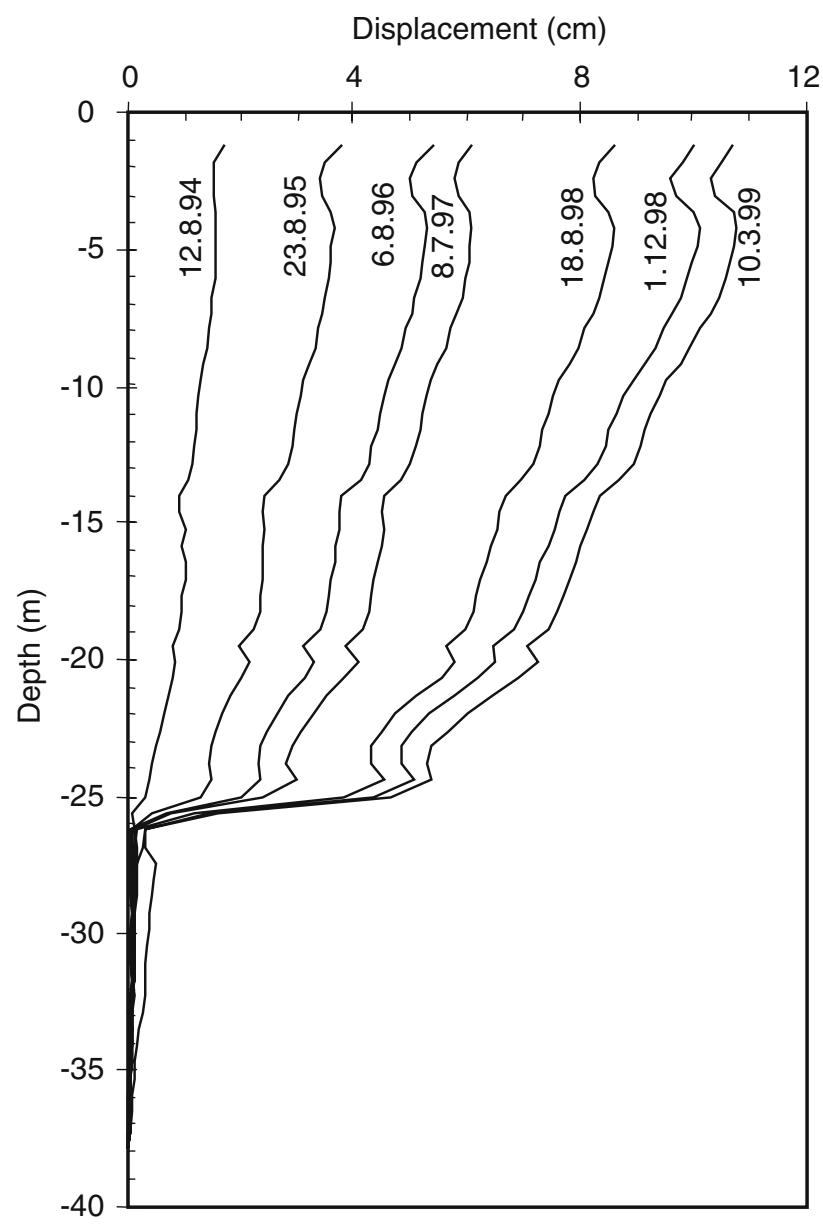

Figure 12. Horizontal deformations measured in the borehole at Site 1 between 1994 and 1999 (Arenson et al., 2002).

and an alternative solution was used in the form of the avalanche and debris-flow retention dam built above Pontresina in 2003.

\subsection{SITE 2: BOREHOLE MONITORING}

The borehole temperatures measured at Site 2 (Figures 14 and 15) indicate that the active layer is consistently warmer and thicker (see also Figure 18) during the summer in borehole B2 (no snow-supporting structures) than in $\mathrm{B} 1$, which is located between the structures. This can probably be attributed to the fact that snow melt is delayed between and above the structures (Phillips et al., 2000) as no avalanches occur there and because snow drifts tend to accumulate in their vicinity (Figure 16). 


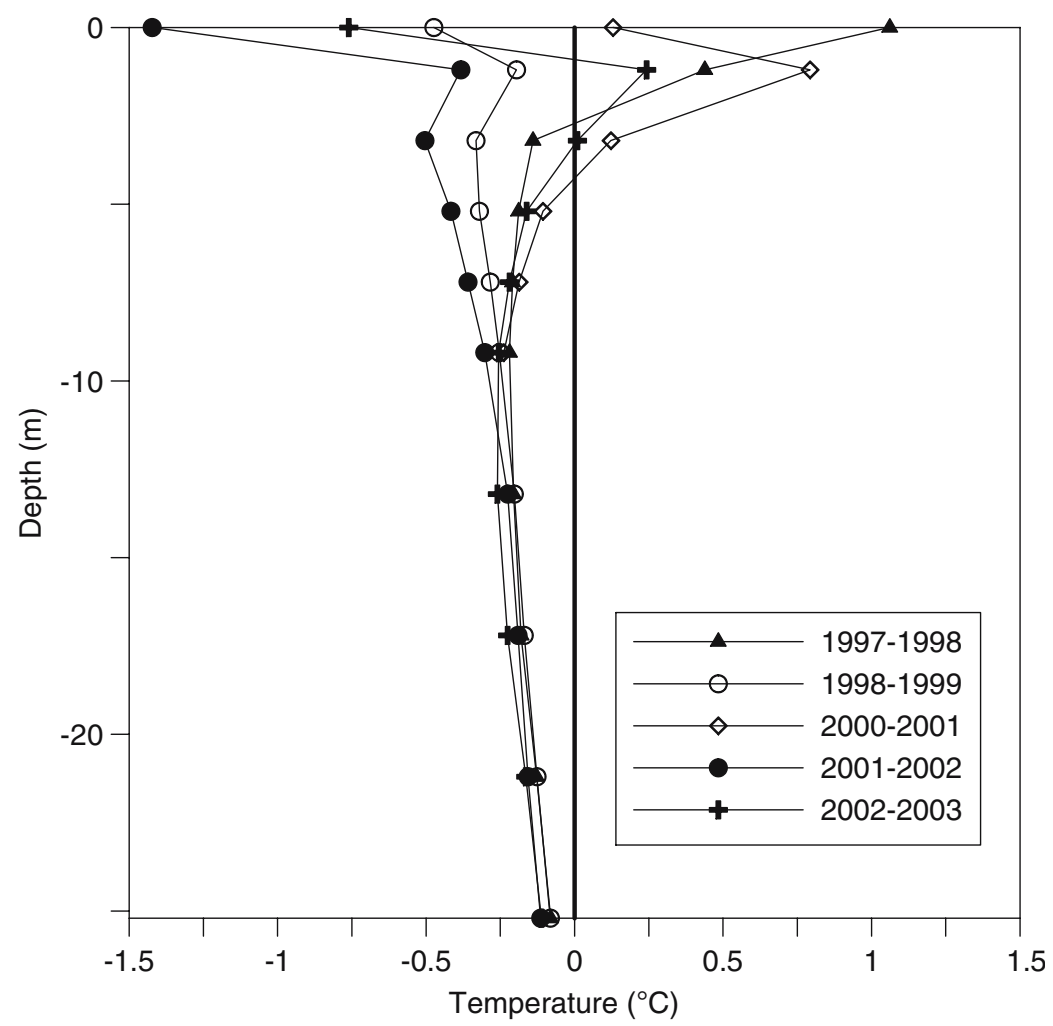

Figure 13. Mean annual vertical borehole temperatures between 1997 and 2003 at Site1. The bold line denotes $0{ }^{\circ} \mathrm{C}$. (NB: 1999-2000 is not shown due to missing data).

Horizontal deformations are much more pronounced in B4 (no snowsupporting structures) than in B3 (Figure 17). In both boreholes, creep mainly affects the active layer, which contains ice during a large part of the year. As creep rates in icy sediments increase with increasing temperatures (Hoelzle et al., 1998), it is probable that the lower creep rates measured between the structures are due to the lower ground temperatures reigning there. The presence of snow-supporting structures does not have a slope-stabilizing effect as the anchor strengths required would be impossible to attain (Thalparpan, 2000).

The ground temperatures at Site 2 are distinctly colder than that at Site 1. This can be attributed to altitude and orientation, but also to the fact that the borehole at Site 1 is located in relatively flat terrain just above the steep rock glacier tongue, whereas the boreholes at Site 2 are located directly in a steep blocky slope. In the latter type of terrain, up- and downslope air circulation between the blocks (also in winter, underneath the snow cover) probably plays an important role in lowering ground temperatures (Neher, 1939; Delaloye, 2004). 

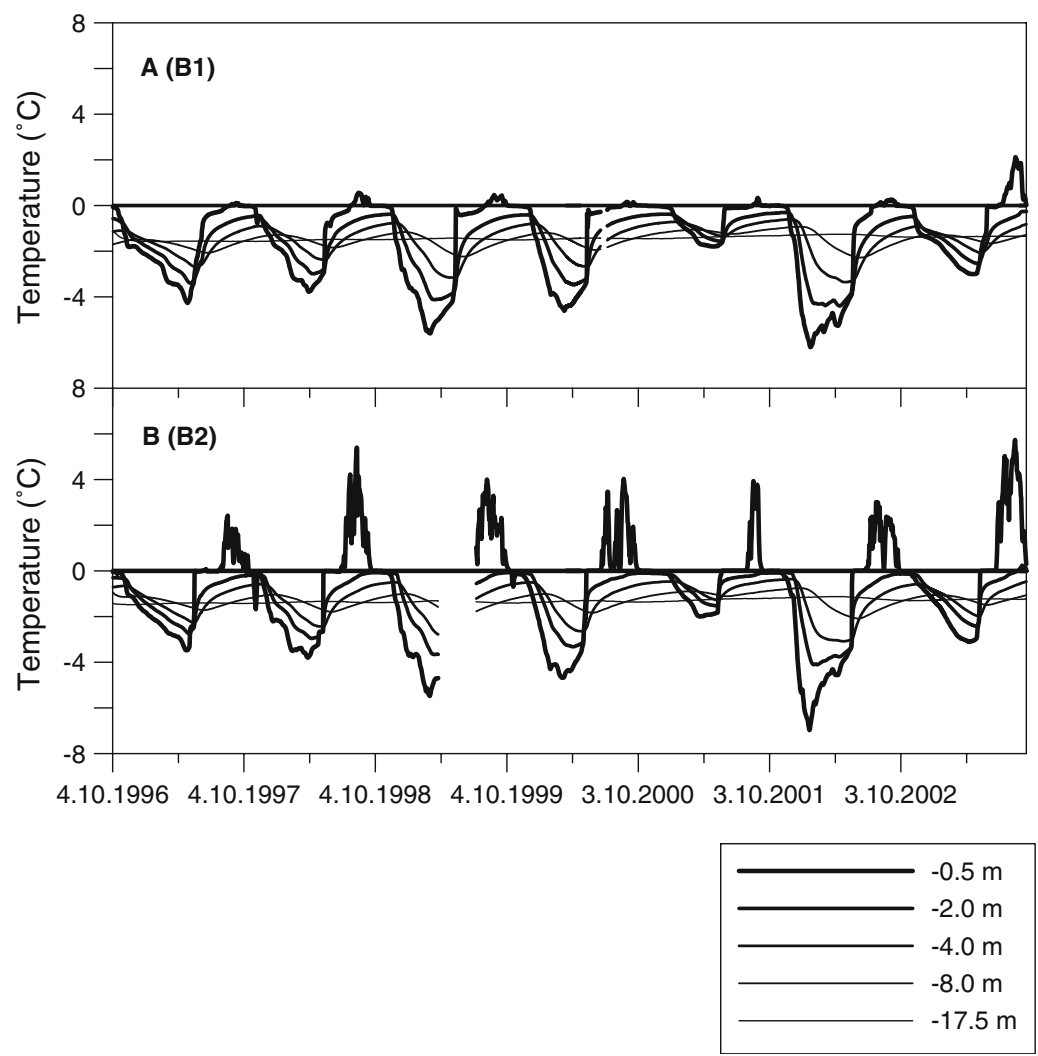

Figure 14. Borehole temperatures measured in boreholes B1 (A, top) (between the snow-supporting structures) and B2 (B, bottom - reference borehole) between 1996 and 2003 at the depths of $0.5,2.0,4.0,8.0$ and $17.5 \mathrm{~m}$.

\subsection{EVOLUTION OF ACTIVE LAYER DEPTHS AT BOTH SITES}

Determination of active layer thickness can be difficult in ice-rich rock glaciers, due to changes in mass balance. However, vertical displacements of the rock glacier surface at Site 1 have been determined photogrametically (Kääb, 1996; Hoelzle et al., 1998, Kääb and Völlmer, 2001) and have shown that the elevation differences are less than $2 \mathrm{~cm}_{\text {year }}{ }^{-1}$, which is negligible here, as maximum active layer thickness as determined thermally (Figure 18) has varied between 3 and $5 \mathrm{~m}$. These fluctuations in active layer thickness imply that the potential amount of material which can be entrained in the event of a debris flow in the Laviner Giandains gully in summer is highly variable.

The boreholes at both sites registered an increase in active layer depth in the exceptionally warm summer of 2003 , but the active layer was almost equally deep in the summers 2000 and 2001 at Site 1. The thickness of the 


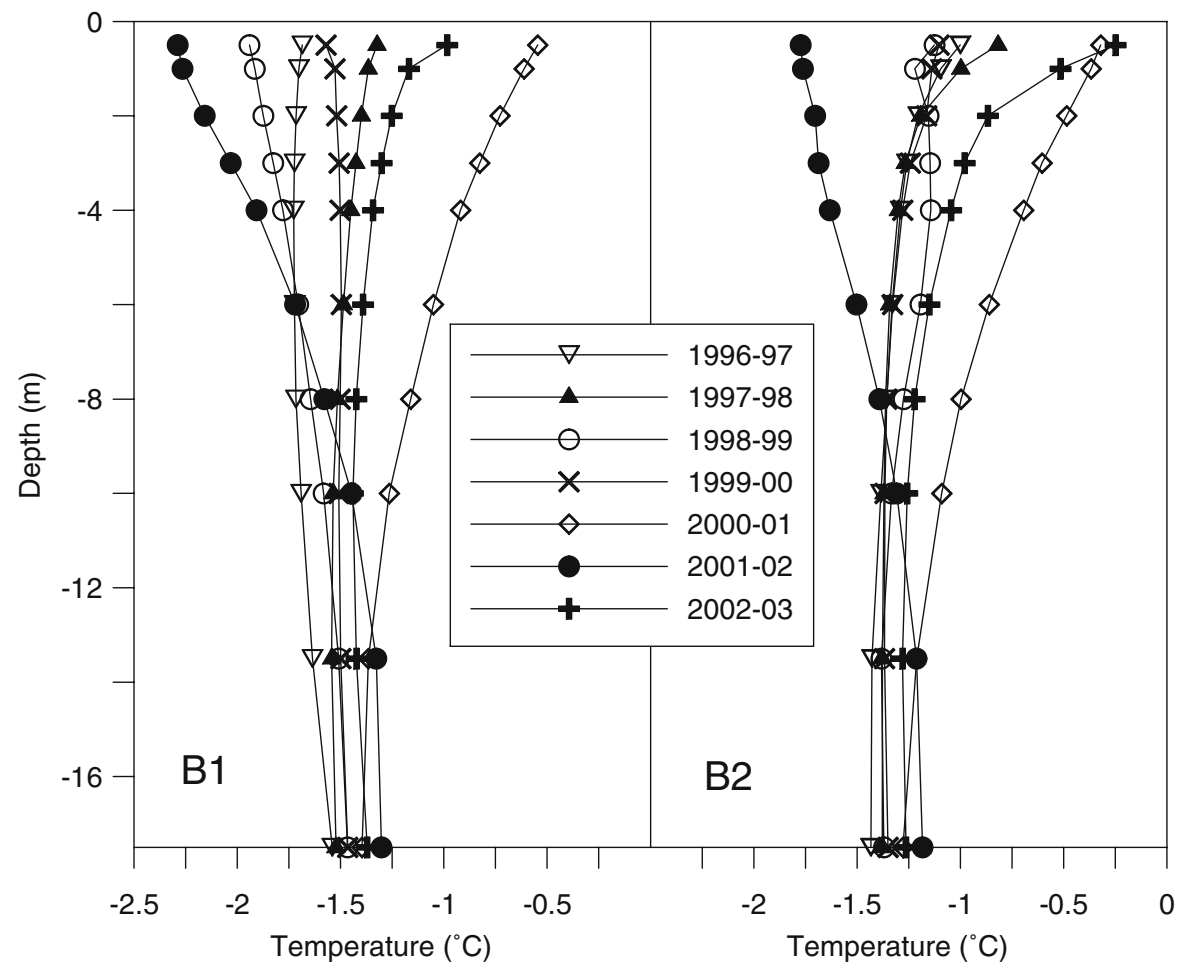

Figure 15. Mean annual vertical borehole temperatures in B1 and B2 between 1996 and 2003.

active layer is dependent on the duration of the snow cover, air temperature in the absence of a snow cover, surface roughness, pore size and air circulation between the blocks, direct solar radiation and a number of other influencing factors. Active layer depths at Site 2 are probably less variable because the site is shadier and about $300 \mathrm{~m}$ higher, implying that mean annual air temperatures are lower and the snow cover duration is longer, protecting the ground from direct solar radiation and warm summer air temperatures. B1 has the shallowest active layer depth, which can be attributed to the fact that snow cover duration is longest between the snow-supporting structures.

The fact that boreholes are point measurements should be emphasized active layer depth is probably quite variable over the entire surface of the slope. Whereas the maximum active layer depth measured in boreholes B1 and B2 at Site 2 was 2.6 and 3.4 m, respectively in August 2003, ice lenses were observed at the same time at a depth of only $1.6 \mathrm{~m}$ in trenches which were dug between the two boreholes. 


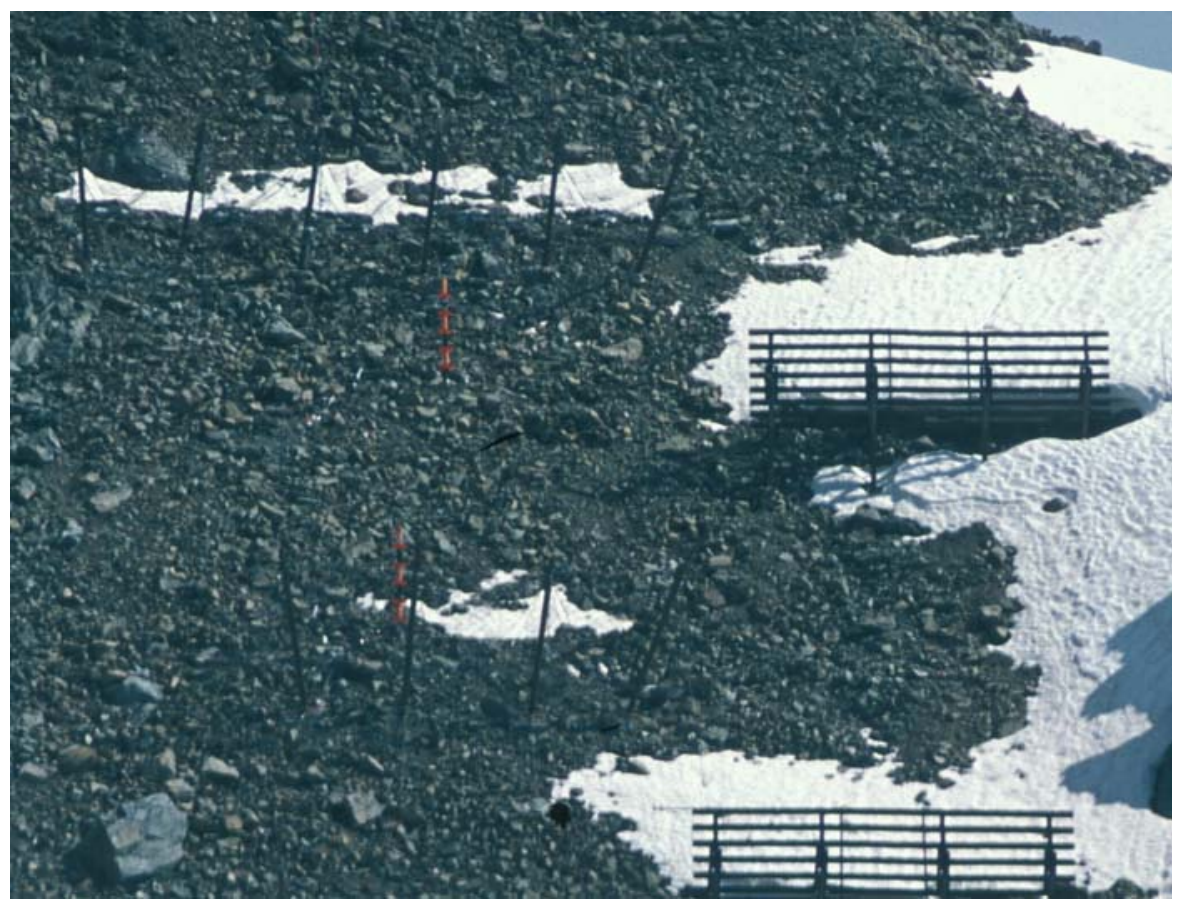

Figure 16. Delayed snow melt above the structures at Site 2.

\subsection{SITE 2: EXPERIMENTAL SNOW-SUPPORTING STRUCTURES}

The total mean horizontal displacement of anchors of the same type between 1997 and 2003 is shown in (Figure 19). The positions of 28 anchor heads/foundations (steel ropes, micropiles, tubes and plates) under three types of snow-supporting structure (snow-net, snow-bridge and suspended sledge) were measured annually. The mean displacements of all types of anchors are between 1 and $1.5 \mathrm{~cm}$ year ${ }^{-1}$, which is acceptable according to the new Swiss Guidelines (SLF/BUWAL, 2000). The recommended maximum value of $5 \mathrm{~cm}$ year $^{-1}$ was only exceeded by three rope anchors in 2000-2001 (5.2, 5.3 and $5.7 \mathrm{~cm}$ displacement). In comparison, anchors located at another permafrost site, Wisse Schijen in Valais have creep rates of 5-20 cm year ${ }^{-1}$ (Phillips et al., 2003b). At Site 2 the anchors/foundations under the snow-nets were generally more stable than those under the snow-bridge or suspended sledge.

Whereas air temperature and the temperature of the steel supports fluctuate strongly on a diurnal basis, the temperature of the steel tube anchors remains very stable, below $0{ }^{\circ} \mathrm{C}$. For example, after an initial warming of approximately $3{ }^{\circ} \mathrm{C}$ in May 1998 (probably due to snow melt water infiltration), none of the temperature fluctuations registered on the support can 


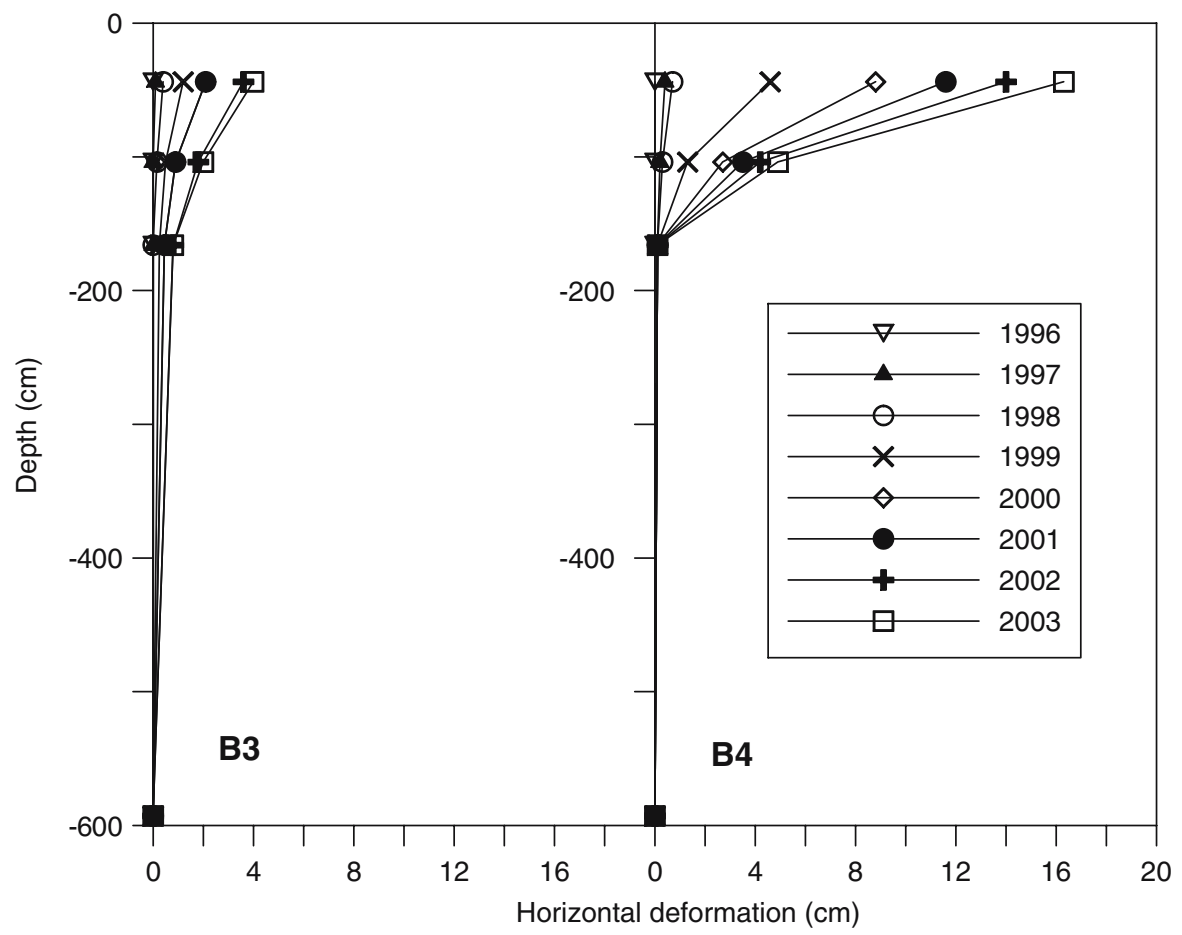

Figure 17. Horizontal deformations measured in boreholes B3 and B4 between 1996 and 2003.

be seen on the anchor (Figure 20). This can be attributed to the poor thermal connections between the support and the anchor and to the fact that the support only warms for a few hours daily. This distinguishes the snowsupporting structures from steel structures such as oil pipelines which are subject to a constant source of heat and therefore have to be raised above the frozen ground and cooled passively in order to prevent melting of ground ice in arctic permafrost (Sorenson et al., 2003).

\subsection{SWISS GUIDELINES FOR THE CONSTRUCTION OF SNOW-SUPPORTING STRUCTURES IN ALPINE PERMAFROST TERRAIN}

The Swiss guidelines (BUWAL/SLF 2000) developed as a result of the analysis of the measurements and tests described in this paper make several recommendations for the construction of snow-supporting structures in unstable permafrost terrain, the most important of which are:

- The presence of permafrost should be investigated before construction by drilling boreholes and measuring ground temperature for at least 1 year. The amount of ice in the ground can be estimated during extraction of drilling material and with drill cores. 


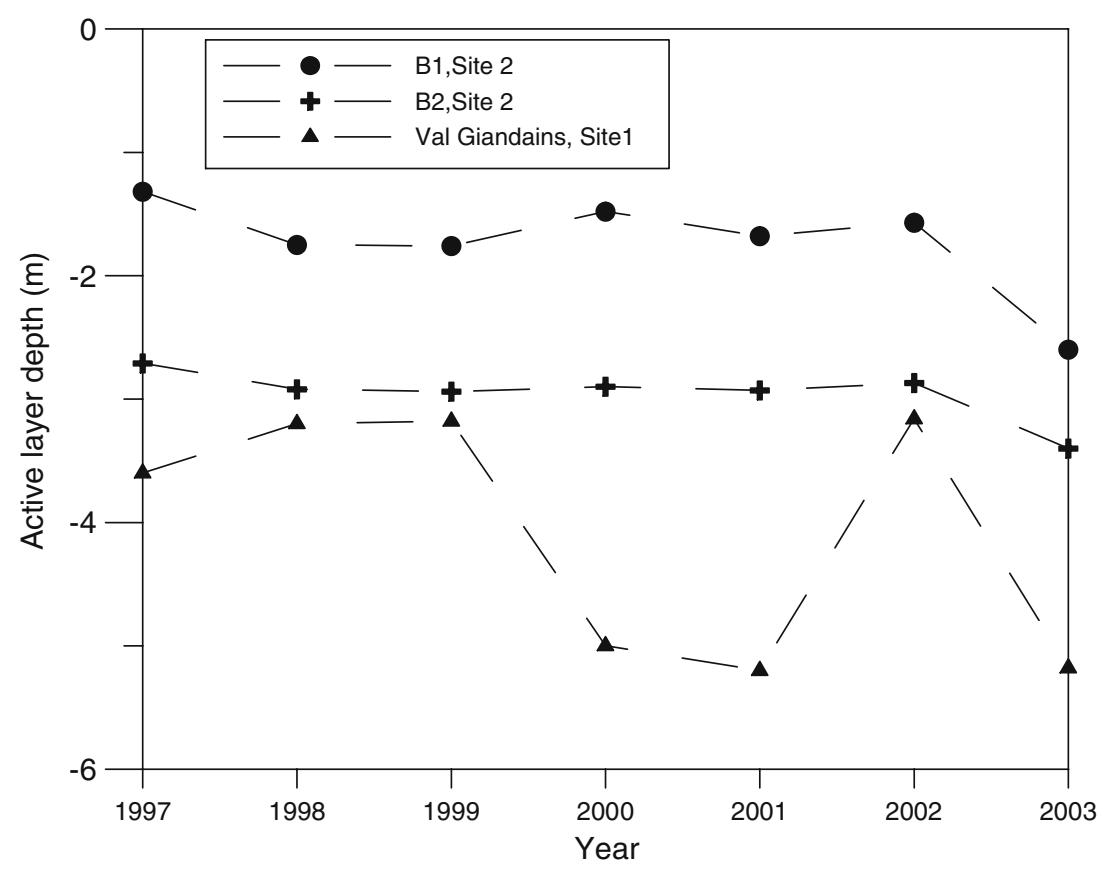

Figure 18. Maximum active layer depths measured in the boreholes at Sites 1 and 2 (B1 and B2) between 1997 and 2003.

- Creep rates of frozen sediments should be measured with inclinometer measurements in boreholes. If creep rates exceed $5 \mathrm{~cm}_{\text {year }}{ }^{-1}$, alternative methods of protection against avalanches should be used if possible (e.g. retention or deflection dams in the avalanche runout zone). If absolutely no alternative is possible, snow-supporting structures can be built, but their mid-term design life is not guaranteed.

- Snow-nets should be used in lieu of snow-bridges on slopes with tolerable creep rates as the geometry of the nets can easily be corrected and they are better adapted to slopes with rockfall activity.

- During the drilling of anchor boreholes, the down-the-hole hammer should be extracted frequently to avoid clogging due to friction melting of permafrost ice. Anchors and foundations should be inserted and grouted immediately to avoid refreezing.

- Final designing of anchors should be effected after in situ anchor pullout tests have been carried out.

- Specially adapted injection grout, suitable for ground temperatures down to $-4{ }^{\circ} \mathrm{C}$ must be used. It must be injected between $20{ }^{\circ} \mathrm{C}$ and $30{ }^{\circ} \mathrm{C}$.

- Monitoring of the structures and the underlying ground is recommended on an annual basis. 


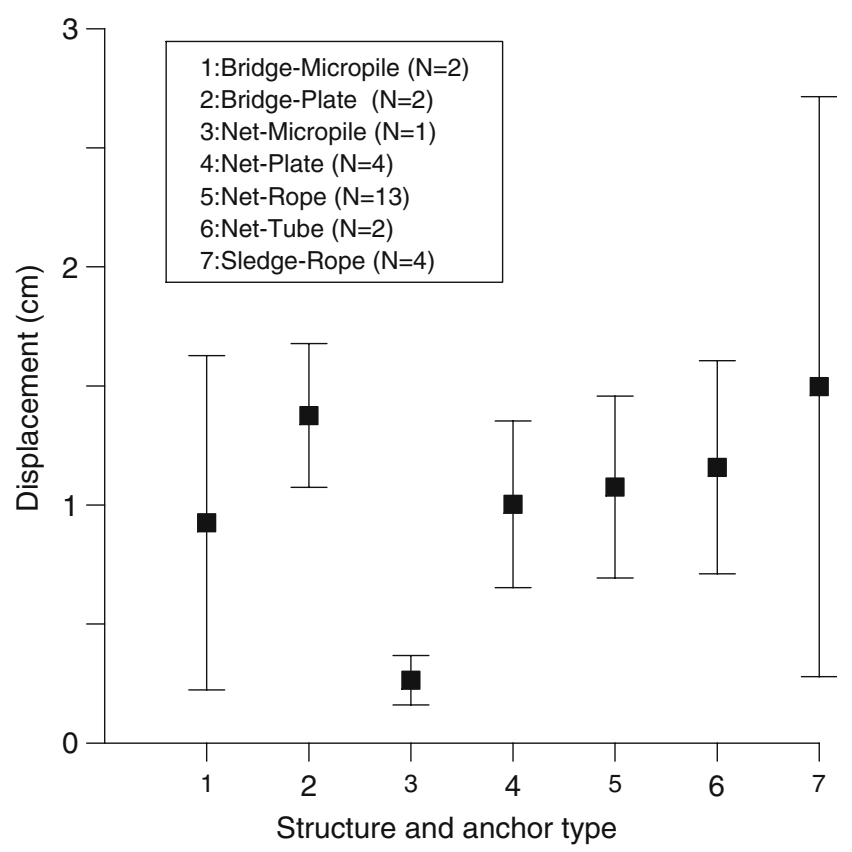

Figure 19. Mean displacement (and standard deviations) of all anchors between 1997 and 2003.

These guidelines have been in practical use in Switzerland since 2000 and will be useful in other countries already using the 1990 Swiss guidelines for the construction of snow-supporting structures (most Alpine countries, Iceland, Japan and Canada).

\section{Conclusions}

Snow-supporting structures should only be built in permafrost terrain if creep rates are less than $5 \mathrm{~cm}_{\text {year }}{ }^{-1}$, volumetric ice content is less than $20 \%$ and if special construction methods are used, as described in the Swiss guidelines for the construction of snow-supporting structures in permafrost (SLF/BUWAL, 2000). Structures can be built at higher creep rates if no other alternative is possible, but their minimum design life of 50 years is not guaranteed. Ice-rich terrain (such as rock glaciers) must be avoided as the technical problems are too complex to ensure efficient, long term avalanche protection. If the terrain is not appropriate and/or other natural hazards are present, alternative types of avalanche protection must be used, as is the case for the Laviner Giandains gully above Pontresina where a combined avalanche/debris flow retention dam was built at the 


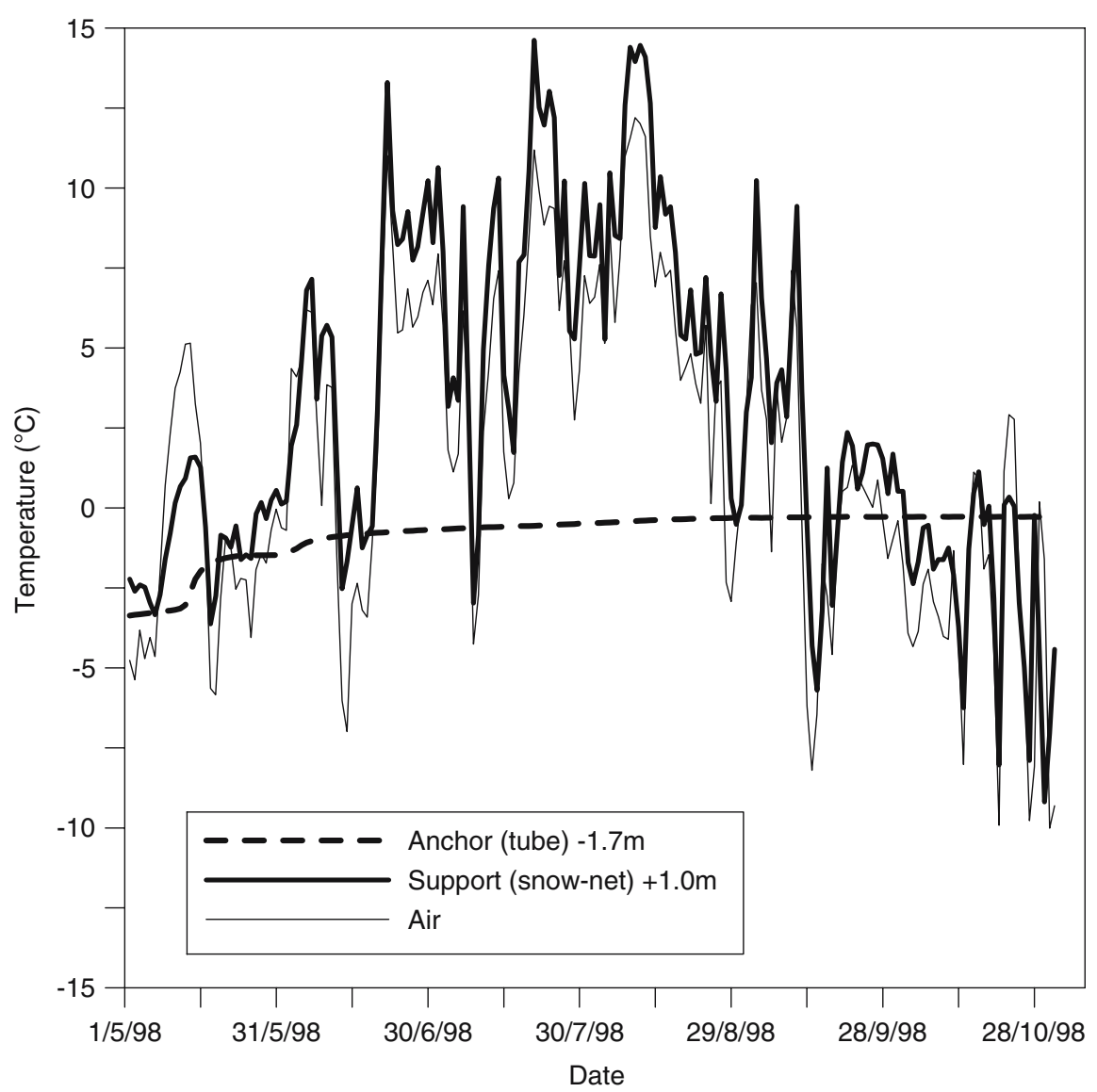

Figure 20. Air temperature, temperature of a support and temperature of an anchor at $1.7 \mathrm{~m}$ depth measured between 1 May and 1 November 1998.

base of the gully. The ideal type of snow-supporting structures for moderately creeping permafrost terrain are snow-nets, as they are highly flexible and well adapted to rock fall. Specially developed building methods have to be used in permafrost, in particular for drilling anchor holes and for grout injection. Guidelines were developed in the context of this project for the construction of snow-supporting structures in permafrost and are currently applied to all construction sites located in permafrost terrain. Monitoring of the experimental structures continues in order to investigate whether any modifications of the guidelines are necessary. It was found that the snow-supporting structures have a slight cooling effect on the underlying permafrost in that they delay snow melt, but that they cannot stabilize a creeping slope. The effects of erosion due to increased snow melt runoff are currently being investigated. The structures do not conduct 
heat into the underlying ground via the steel supports and anchors, as the thermal coupling between these elements is low and because the structures are not constantly subject to heat but only to diurnal warming through direct solar radiation. The creep rates of the experimental structures at Site 2 are generally lower than $5 \mathrm{~cm} \mathrm{year}^{-1}$. Surficial erosion and denudation of the anchors has been observed at Site 2, but it is not yet known whether and at what point the anchors will be pulled out or rupture. It is assumed that in creeping permafrost terrain anchors do not have a design life of 100 years as they do in non-permafrost. The geotechnical and thermal monitoring of the two investigated sites has allowed to obtain valuable information on the stability of permafrost slopes with different ice contents and the evolution of alpine permafrost temperatures since 1996.

Continued monitoring of snow-supporting structures in permafrost terrain is necessary to determine the effects of high creep rates in the layer of scree, which mainly affects the tops of the anchors, as it is not yet known what the long-term consequences to the structures are. Ongoing observations will provide additional information on the ideal combination of structure and anchor types to be used in these particular conditions.

\section{Acknowledgements}

This research project was made possible due to the financial support provided by the Swiss cantons Valais and Grisons and by the Swiss Federal Office for Environment, Forest and Landscape (BUWAL). Stefan Margreth, Walter Ammann, Patrik Thalparpan, Lukas Stoffel, Reto Wetter and Martin Hiller provided valuable support. Lukas Arenson and Martin Hoelzle are thanked for their graphic contributions. Jürg Schweizer, Emmanuel Reynard and an anonymous reviewer provided numerous constructive suggestions to the manuscript.

\section{References}

Arenson, L.: 2002, Unstable Alpine Permafrost: A Potentially Important Natural Hazard Variations of Geotechnical Behaviour with Time and Temperature. ETH Diss. No. 14801. Arenson, L., Hoelzle, M. and Springman, S. M.: 2002, Borehole deformation measurements and internal structure of some rock glaciers in Switzerland, Permafrost Periglac. Proce. 13(2), 117-135.

Coaz, J.: 1910, Statistik und Verbau der Lawinen in der Schweizeralpen/Statistique des avalanches dans les Alpes suisses et des travaux de défense y relatifs. Bern, Stämpfli \& Cie.

Delaloye, R.: 2004, Contribution à l'étude du pergélisol de montagne en zone marginale. GeoFocus 10, Département de Géosciences, Université de Fribourg, Suisse.

EMPA/SLF: 1999, Ankermörtel im Permafrost. Swiss Federal Laboratories for Material Testing and Research EMPA Report no. 200229. 
Gardaz, M.: 1998, Permafrost prospecting, periglacial and rock glacier hydrology in mountain areas - case studies in the Valais Alps, Switzerland. Doctoral thesis no. 1222, Institute of Geography, University of Fribourg, Switzerland.

Haeberli, W.: 1992, Construction, environmental problems and natural hazards in periglacial mountain belts, Permafrost Periglac. Proce. 3, 111-124.

Haefeli, R.: 1954, Fundationsprobleme des Lawinenverbaues. Mitt. der Versuchsanstalt für Wasserbau und Erdbau, ETH Zurich, Report no. 32.

Heimgartner, M.: 1988, Ankerzugversuche im Verbaugebiet Giandains II, Gemeinde Pontresina, Swiss Federal Institute for Snow and Avalanche Research, Davos, Expertise no. G88.10.

Hinkel, K. M. and Outcalt, S. I.: 1994, Identification of heat-transfer processes during soil cooling, freezing and thaw in Central Alaska, Permafrost Periglac. Proce. 5, 217-235.

Hoelzle, M., Wagner, S., Kääb, A. and Vonder Mühll, D.: 1998, Surface movement and internal deformation of ice-rock mixtures within rock glaciers at Pontresina Schafberg, Upper Engadin, Switzerland. In: A. G. Lewkowicz and M. Allard (eds), Proceedings of the 7th International Conference on Permafrost, Yellowknife, Canada, pp. 465-471.

Johnson, J. P. and Nickling, W. G.: 1979, Englacial temperature and deformation of a rock glacier in the Kluane Range, Yukon Territory, Canada, Can. J. Earth Sci. 16, 2275-2283.

Kääb, A.: 1996, Photogrammetrische Analyse von Gletschern und Permafrost, Vermessung Photogrammetrie Kulturtechnik 12(1996), 639-644.

Kääb, A. and Völlmer, M.: 2001, Digitale photogrammetrie zur Deformationsanalyse von Massenbewegungen im Hochgebirge, Vermessung Photogrammetrie Kulturtechnik 8(2001), 538-543.

Keller, F., Haeberli, W., Rickenmann, D. and Rigendinger, H.: 2002, Dämme gegen Naturgefahren: Bau von Schutzdämmen gegen Rüfen und Lawinen in Pontresina, Tec 21 17, $13-17$.

Margreth, S., Harvey, S., and Wilhelm, C.: 2000, Effectiveness of long term avalanche defence measures in winter 1999 in Switzerland. Proceedings of the International Snow Science Workshop, Big Sky, Montana, October 1st-6th 2000, pp. 501-508.

Neher, J.: 1939, Beobachtungen über Luftzirkulation in der Schneedecke, In: H. Bader, R. Haefeli, E. Bucher, J. Neher, O. Eckel and C. Thams (eds), Der Schnee und seine Metamorphose, Bern: Kümmerly \& Frey.

Phillips, M.: 2000, Influences of Snow-supporting Structures on the Thermal Regime of the Ground in Alpine Permafrost Terrain, Swiss Federal Institute for Snow and Avalanche Research, Davos.

Phillips, M., Bartelt, P. and Christen, M.: 2000, Influences of avalanche-defence structures on ground temperature in Alpine permafrost terrain, Ann. Glaciol. 21, 422-426.

Phillips, M., Arenson, L., Kääb, A. and Hoelzle, M.: 2002, Dem Permafrost oberhalb von Pontresina auf der Spur: vielfältige Untersuchungen geben Aufschluss über den Zustand des Blockgletschers, Bündnerwald 4(02), 79-83.

Phillips, M., Margreth, S., Stoffel, L. and Ammann, W.J.: 2003a, Development of Swiss Guidelines for the construction of snow-supporting structures in creeping alpine permafrost terrain. In: P. J. Culligan, H. H. Einstein, and A. J. Whittle (eds), Proc. 12th Panamerican Conference on Soil Mechanics and Geotechnical Engineering, Vol. 2, MIT Boston, June 2003, pp. 2603-2610.

Phillips, M., Margreth, S. and Ammann, W. J.: 2003b, Creep of snow-supporting structures in alpine permafrost. Permafrost. In: M. Phillips, S. Springman, and L. Arenson (eds), Proc. 8th International Conference on Permafrost, Zurich, July 2003, 891-896, Balkema, Netherlands, 1320 pp. 
Rist, A. and Phillips, M.: 2005, First results of investigations on hydrothermal processes within the active layer above alpine permafrost in steep terrain, Norwegian J. Geogr. 59, 177-183, Oslo.

SLF/BUWAL: 1990, Richtlinien für den Lawinenverbau im Anbruchgebiet, EDMZ, Bern.

SLF/BUWAL: 2000, Richtlinie für den Lawinenverbau im Permafrost, EDMZ, Bern.

Sorenson, S., Smith, J. and Zarling, J.: 2003, Thermal performance of TAPS heat pipes with non-condensable gas blockage. In: M. Phillips, S. Springman, and L. Arenson (eds), Proc. 8th International Conference on Permafrost, Zurich, July 2003, 1097-1102, Balkema, Netherlands, 1320 pp.

Stoffel, L.: 1995, Bautechnische Grundlagen für das Erstellen von Lawinenverbauungen im Alpinen Permafrost. Report no. 52, Swiss Federal Institute for Snow and Avalanche Research.

Thalparpan, P.: 2000, Lawinenverbauungen im Permafrost, Swiss Federal Institute for Snow and Avalanche Research, Davos.

VAW: 1992, Pontresina Schafberg: Bericht über die Bohrungen und Bohrlochmessungen im Permafrostbereich der Lawinenverbauungszone. Report No. 80.2, Laboratory of Hydraulics, Hydrology and Glaciology, ETH Zurich.

Vonder Mühll, D. and Holub, P.: 1992, Borehole logging in Alpine permafrost, Upper Engadin, Swiss Alps, Permafrost Periglac. Proce. 3, 125-132.

Vonder Mühll, D.: 1993, Geophysikalische Untersuchungen im Permafrost des Oberengadins. VAW Mitteilung 122. Versuchsanstalt für Wasserbau, Hydrologie und Glaziologie der Eidgenössichen Technischen Hochschule Zürich.

Vonder Mühll, D., Stuck, T., and Haeberli, W.: 1998, Borehole temperatures in Alpine permafrost: a ten year series. In: A. G. Lewkowicz and M. Allard (eds), Proceedings, Seventh International Conference on Permafrost, Yellowknife, Canada, June 23-27, 1998, 1089-1090, Collection Nordicana. 